\title{
An experimental investigation of the flexural strength of soda-lime-silica glass at high loading rates
}

Meyland, Martin J.; Bønding, Casper K. T.; Eriksen, Rasmus N.W.; Nielsen, J.H.

\section{Published in:}

Glass Structures \& Engineering

Link to article, DOI:

10.1007/s40940-018-0089-2

Publication date:

2019

Document Version

Peer reviewed version

Link back to DTU Orbit

Citation (APA):

Meyland, M. J., Bønding, C. K. T., Eriksen, R. N. W., \& Nielsen, J. H. (2019). An experimental investigation of the flexural strength of soda-lime-silica glass at high loading rates. Glass Structures \& Engineering, 4(2), 175183. https://doi.org/10.1007/s40940-018-0089-2

\section{General rights}

Copyright and moral rights for the publications made accessible in the public portal are retained by the authors and/or other copyright owners and it is a condition of accessing publications that users recognise and abide by the legal requirements associated with these rights.

- Users may download and print one copy of any publication from the public portal for the purpose of private study or research.

- You may not further distribute the material or use it for any profit-making activity or commercial gain

- You may freely distribute the URL identifying the publication in the public portal 


\title{
An Experimental Investigation of the Flexural Strength of Soda-Lime-Silica Glass at High Loading Rates
}

\author{
Martin Jensen Meyland · Casper Kirkeberg Tchu Bønding · Rasmus Normann \\ Wilken Eriksen · Jens Henrik Nielsen
}

Received: date / Accepted: date

\begin{abstract}
A novel ring-on-ring test setup was developed for investigating the biaxial flexural strength of small circular soda-lime-silica glass specimens at high loading rates in a high-speed test rig. Such rate effects becomes important when designing for extreme events such as impact and blast, which are highly relevant for glass used in e.g. façades.

The investigation focused on two groups of specimens with different surface conditions: as-received and pre-damaged with a well-defined flaw. A total of 151 specimens were tested in order to evaluate the influence of loading rate and surface condition on the flexural strength. Quasi-static and dynamic experiments were performed at loading rates ranging between 2 to $5.6 \cdot 10^{6} \mathrm{MPa} / \mathrm{s}$. An $85 \%$ increase in strength with loading rate was observed for the 'as-received' specimens and $52 \%$ for the 'pre-damaged'.
\end{abstract}

Keywords Soda-lime-silica glass · High loading rates · Strain rates $\cdot$ Ring-on-ring test $\cdot$ Dynamic testing $\cdot$ Flexural strength $\cdot$ Material characterisation $\cdot$ Blast and impact

\section{Introduction}

The use of glass in construction has increased significantly over the last decades. Especially in modern architecture, the use of façade glazing has been a design feature for years, where the function of glass is to protect the building from

M. J. Meyland $(\bowtie) \cdot$ C. K. T. Bønding · J. H. Nielsen

Department of Civil Engineering

Technical University of Denmark, Brovej, Building 118

2800 Kgs. Lyngby, Denmark

E-mail: majeme@byg.dtu.dk

R. N. W. Eriksen

Department of Mechanical Engineering

Technical University of Denmark, Nils Koppels Allé, Building 404 2800 Kgs. Lyngby, Denmark the outside conditions, still allowing for daylight and views. However, glass is also one of the most brittle materials used in buildings today. This raises questions related to safety issues regarding e.g. extreme loads such as nearby explosions and hazards in general. It is well-known that in the event of an explosion, debris of glass can be accelerated to velocities posing a serious threat to humans (Norville et al. 1999; Norville 2000).

Studies of laminated glass exposed to high loading rates have been reported in the scientific literature (Hooper et al. 2012; Larcher et al. 2012; Zhang et al. 2013; Kuntsche 2015; Pelfrene 2016; Del Linz et al. 2017). However, the focus has been on the laminate while the glass itself has attracted less interest.

For predicting failure, the strength of glass is considered as one of the key parameters. However, the strength is challenging to determine, especially at high loading rates relevant for blast loads. Likewise, it must be considered crucial to have a proper knowledge about the dynamic glass strength when designing the substructure of a façade, as the amount of blast energy that can be absorbed by the glass until failure is an important factor. A few attempts on investigating the dynamic flexural strength of borosilicate glass using a four-point bending setup and a ring-on-ring test have been reported (Nie et al. 2009, 2010). Both studies demonstrate a loading rate dependency. The dynamic strength of float glass was also studied utilising a Split-Hopkinson pressure bar (SHPB) test setup. Here a strong correlation between strength and loading rate was also found (Peroni et al. 2011; Zhang et al. 2012).

Normally, the strength of glass is known to be insensitive to moderate loading rates when focusing on long-term loads in the sense of life time predictions. This is well described by the phenomenon of stress corrosion causing sub-critical crack growth (Wiederhorn 1967; Wiederhorn and Bolz 1970; Evans and Wiederhorn 1974; Michalske and Freiman 1983). But 
how do high loading rates affect the strength of glass where the effect of sub-critical crack growth possibly may be decreased? This paper will as a part of a pilot study experimentally investigate the loading rate effects of the biaxial flexural strength of soda-lime-silica glass using a small ring-on-ring test in a specially designed servo-hydraulic high-speed test rig.

\section{Experimental Details}

Circular soda-lime-silica glass specimens (discs) with a diameter, $D$, of $45 \mathrm{~mm}$ were produced for the investigations. The average measured thickness of the specimens was $2.85 \mathrm{~mm}$ ranging between $2.82 \mathrm{~mm}$ and $2.90 \mathrm{~mm}$. The present study focused on two different types of surface treatments without taking into account the production related air- or tin side. The majority of the specimens were tested with an untreated surface (as-received). To assess the effect of the surface conditions, a small series was scratched on the tensile surface with a well-defined flaw using a Universal Surface Tester (UST-1000) from the company Innowep. With a penetration force of $500 \mathrm{mN}$, the scratch was induced centrally on the specimen with a length of $2.5 \mathrm{~mm}$ in accordance with the properties proposed by Schula (2015) and Hilcken (2015), representing a realistic flaw that can be found on glass panes in consequence of e.g. ageing (see also Datsiou and Overend 2017a,b).

Using a scanning electron microscope (SEM) together with an energy dispersive X-ray spectroscopy (EDS), a chemical elemental composition as expected for soda-lime-silica glass according to EN 572-1:2012 (2012) was found.

Previous studies investigating the dynamic flexural strength of borosilicate glass were using a coaxial ring-on-ring test setup to prevent the influence from edge flaws (Nie et al. 2010). In the present study, a similar setup was used in accordance with ASTM C1499 (2015) to investigate the flexural strength using a custom-made servo-hydraulic high-speed test rig with a load capacity of $50 \mathrm{kN}$. The test rig was capable of achieving piston velocities up to $5 \mathrm{~m} / \mathrm{s}$ in a closed controlled loop resulting in loading rates for the tests comparable to SHPB tests.

The test setup was built up by two concentric steel rings; a load ring and a support ring, with outer diameters of $12.5 \mathrm{~mm}$ and $30 \mathrm{~mm}$, respectively, both produced with a tip radius of $2.5 \mathrm{~mm}$. An image of the described test setup is shown in Figure 1 , where the mentioned ring dimensions are highlighted.

To ensure a uniform pressure distribution at the contact surfaces between the rings and the glass specimen, a spherical steel washer (hardness $550 \pm 100 \mathrm{HV} 10$ ) was placed underneath the support ring that prevented stress concentrations to be introduced due to misalignment. The extended part containing the load ring was equipped with 3 linear strain

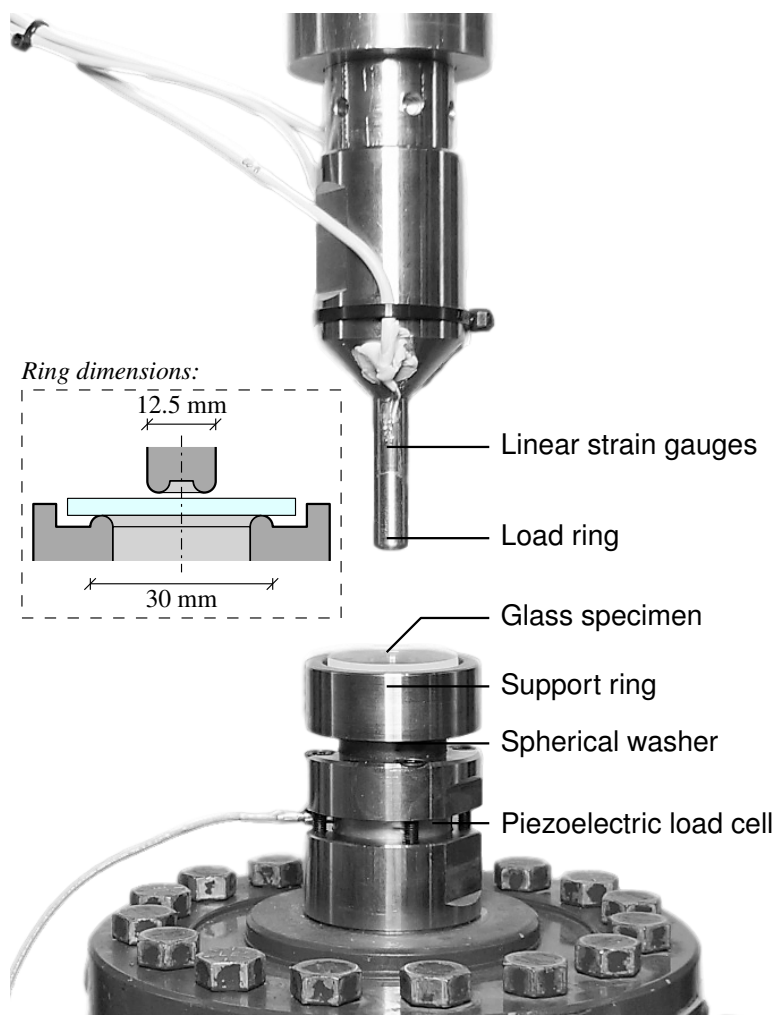

Fig. 1 Ring-on-ring test setup mounted to the custom-made test rig. The dimensions of the load ring and support ring are highlighted in the box.

gauges to measure the load applied concentrically to the specimens. Furthermore, a piezoelectric load cell was added to the bottom part carrying the support ring, which also was capable of measuring the failure load of the tested glass. This was used to check whether the forces at load and support ring were equal. The failure mechanism was investigated by means of a high-speed camera and an explicit finite element model of the experiment. From these, it was clear that the failure originated in the proximity of the specimen centre and bending was, by far, the dominant mechanism.

During the experiments the temperature of the testing environment was $22^{\circ} \mathrm{C}$, with a relative humidity of $30 \%$.

\section{Results and Discussions}

Biaxial flexural strength tests were conducted on both specimen types - as-received and pre-damaged - at 6-7 different loading rates in the range of $2-5.6 \cdot 10^{6} \mathrm{MPa} / \mathrm{s}$. These rates were achieved at target piston velocities of $1.7 \cdot 10^{-3} \mathrm{~mm} / \mathrm{s}$, $0.05 \mathrm{~mm} / \mathrm{s}, 1 \mathrm{~mm} / \mathrm{s}, 10 \mathrm{~mm} / \mathrm{s}, 100 \mathrm{~mm} / \mathrm{s}, 1000 \mathrm{~mm} / \mathrm{s}$ and $3000 \mathrm{~mm} / \mathrm{s}$. However, the actual introduced loading rate varied due to the velocity change of the piston at impact with the specimen. The majority of tests were performed on the untreated specimens with at least 10 tests at each loading rate which is in line with the specifications stated in ASTM 
C1499 (2015). Some loading rates required more tests as they showed a larger scattering in the results. As it only was feasible to pre-damage a small amount of the glass specimens, the number of valid tests for each loading rate was below 10 for this group of specimens tested. Typical load signals from dynamic ring-on-ring experiments are given in Figure 2 for two different loading rates, of which it can be seen that it was possible to load the specimens with a constant rate.

(a) Piston velocity $=10 \mathrm{~mm} / \mathrm{s}$

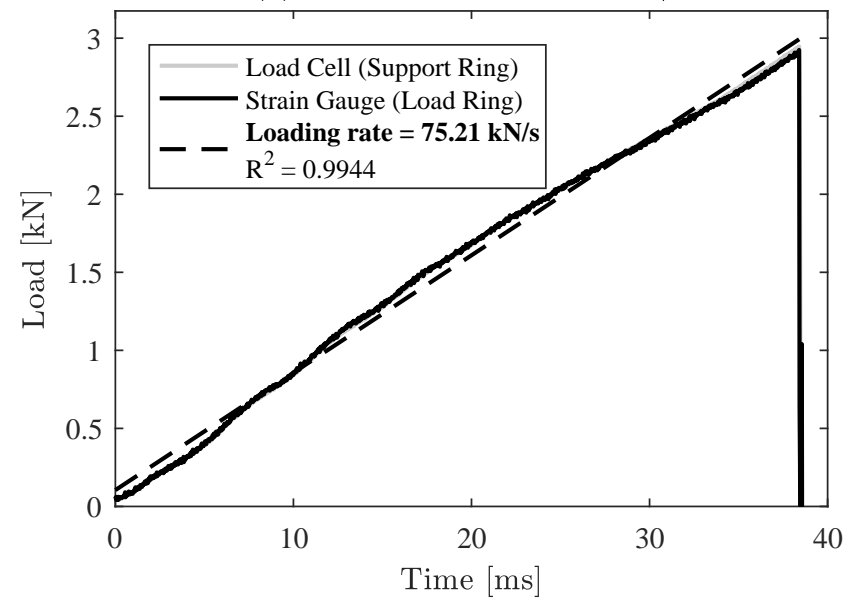

(b) Piston velocity $=100 \mathrm{~mm} / \mathrm{s}$

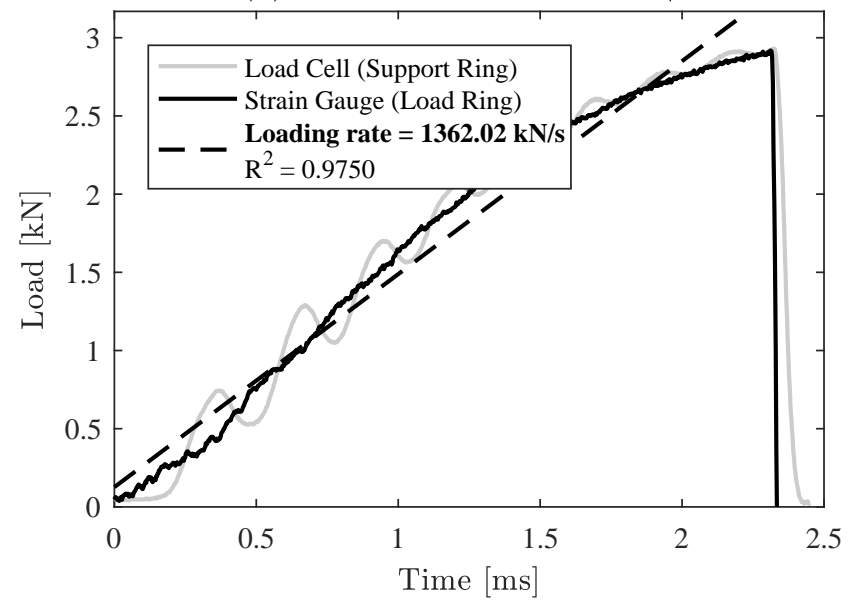

Fig. 2 Typical load signals from dynamic ring-on-ring experiments recorded at piston velocities of (a) $10 \mathrm{~mm} / \mathrm{s}$ and (b) $100 \mathrm{~mm} / \mathrm{s}$.

However, some challenges regarding the load signals recorded from the piezoelectric load cell were observed. At high loading rates the load cell started to oscillate by the impact on the glass specimen (as the eigenfrequency of the load cell most likely was hit). At a piston velocity of about $100 \mathrm{~mm} / \mathrm{s}$ the oscillations became so severe that it was difficult to demonstrate force equilibrium for velocities above it, although no indications that this was not the case were found.
For loading curves below that velocity, a clear coincidence between the load signals from the load ring and support ring was seen.

A few tests were recorded with a high-speed camera, all indicating a bending induced failure mechanism, as the origin of the crack started under the load ring where also the maximum tensile stresses were assumed to appear. An example of one of the high-speed recordings is given in Figure 3, where three sequential frames are illustrating the crack development. The pre-damaged specimens failed in the same manner with a crack initiation starting from the applied scratch. Due to the test setup, the view on the tensile side of the specimens was blocked by the load ring. To further investigate the failure mechanism, an axisymmetric explicit FE-model of the problem was set up to check the stress state in the specimen during loading. The glass specimen is modelled together with the ring tips, both having a frictionless contact to the specimen surfaces. The support ring is fixed in the horizontal and vertical direction whereas the load ring is allowed to move vertically. In the simulation, a velocity of $1000 \mathrm{~mm} / \mathrm{s}$ is chosen for the load ring resulting in a similar load history as the one used in the high-speed recordings. Figure 4 illustrates the distribution of the max principal stresses after $126 \mu \mathrm{s}$ of loading. It is seen that the plate is subjected to (almost) pure bending supporting the findings seen from Figure 3. A similar stress state is found for the highest loading rate at $3000 \mathrm{~mm} / \mathrm{s}$.

Once the failure load of the glass specimen is established and force equilibrium is ensured, the biaxial flexural strength can be calculated by means of plate bending theory (see e.g. Timoshenko and Woinowsky-Krieger 1976):

$\sigma_{f}=\frac{3 F}{2 \pi h^{2}}\left[(1-v) \frac{D_{S}^{2}-D_{L}^{2}}{2 D^{2}}+(1+v) \ln \frac{D_{S}}{D_{L}}\right]$

where $F$ is the recorded peak load, $h$ is the specimen thickness, $D_{S}$ is the support ring diameter, $D_{L}$ is the load ring diameter, $D$ is the specimen diameter and $v$ is the Poisson's ratio of soda-lime-silica glass $(v=0.23)$. This theory, however, is only applicable for linear elastic problems with small deflections neglecting all shear contributions to the deflection. Therefore, a simple axisymmetric FE-model including geometrically non-linear behaviour was used to check the applicability of Eq. (1). The results showed a deviation of $3 \%$ leading to the conclusion that the applied theory is sufficient to describe the strength of the specimens.

Under the assumption that $E=70 \mathrm{GPa}$ and $v=0.23$ remains unchanged during the tests, a strain rate, $\dot{\varepsilon}$, can be calculated by the following expression as the stresses within the area of the load ring are rotationally symmetrical:

$\dot{\varepsilon}=\dot{\sigma} \frac{1-v}{E}$

where $\dot{\sigma}$ is a stress rate based on the relationship stated in Eq. (1) using a loading rate for $F$. 

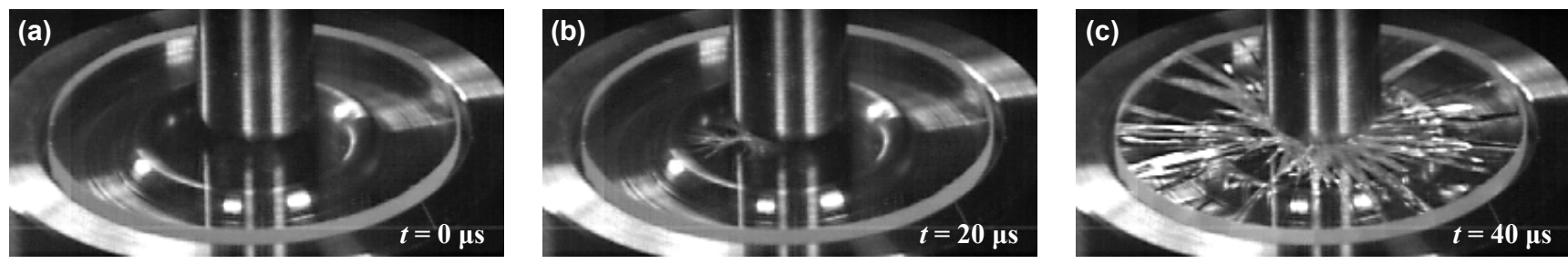

Fig. 3 Three sequential frames from a high-speed camera recording indicating bending failure for an experiment with a piston velocity of $1000 \mathrm{~mm} / \mathrm{s}$ : (a) loading of specimen immediately prior to crack initiation, (b) crack initiation under the load ring and (c) total failure of specimen. The stated times indicates the time interval between the frames. (Photron FASTCAM-APX RS, 50.000 fps, shutter $4.1 \mu$ s, resolution $256 \times 128$ px)

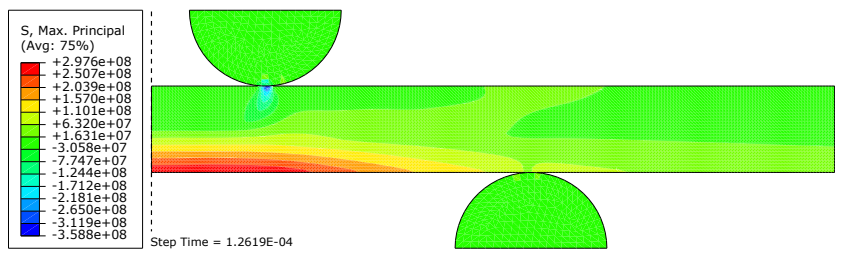

Fig. 4 Distribution of max principal stresses in a glass specimen with a thickness of $2.85 \mathrm{~mm}$ (mean thickness) shown for a loading time equal to $126 \mu$ s (velocity applied to load ring $=1000 \mathrm{~mm} / \mathrm{s}$ ). The results are based on an axisymmetric explicit FE-model in Abaqus CAE.

The calculated flexural strengths for soda-lime-silica glass at different loading rates are presented in Table 1 for the as-received and pre-damaged specimens. It follows from the results that the flexural strength is strongly affected by the applied surface conditions as the pre-damage reduces the strength with about $70 \%$. Furthermore, it reduces the scattering of the results significantly. Above all, the experimental results are showing a loading rate sensitivity of the flexural strength. For both surface conditions tested, the strength is increasing with loading rate. Comparing the lowest strength (quasi-static) with the highest obtained one, an increase of $85 \%$ is noticed for the as-received specimens and $52 \%$ for the pre-damaged. However, the results for the as-received specimens are having large standard deviations ranging from $20 \%$ to $40 \%$ of the averaged strengths, indicating a large variation of flaw sizes on the surface. These findings are comparable with results obtained by Swab et al. (2014). In fact, one could say that there is no strength increase due to the high standard deviations. However, since the development of the averaged strengths is similar to the one found by Nie et al. (2010) for borosilicate glass, an increase might have been present. This is also the case for the pre-damaged specimens despite the fact that the number of tests was very limited.

To rule out the concern about the large standard deviations disturbing the increase in strength, the test results were subjected to a one-way ANOVA testing the following null hypothesis:

$H_{0}: \quad \mu_{1}=\mu_{2}=\mu_{3}=\cdots=\mu_{k}$ where $\mu$ is the group mean and $k$ the number of groups tested. The test clearly shows a statistically significant difference in strength between the tested loading rates, leading to the conclusion that a strength increase as function of loading rate was present for the as-received as well as for the pre-damaged specimens, i.e. the null hypothesis has been rejected. The main results of this analysis are given in Table 2.

At the fourth tested loading rate, a drop in strength is observed for both surface conditions tested. This is likely to be attributed to some systematic factors. However, no obvious factors have been found and more tests are needed to completely rule out the possibility of random scattering in the results. Results obtained at the highest loading rates are based on experiments where it was not possible to prove force equilibrium. However, they are following the trend of the strength development quite well, strongly indicating equilibrium.

The strength increase at high loading rates can be explained by the decrease (or absence) of sub-critical crack growth at the rapid loading rate used. As this mechanism is governed by a chemical reaction at the crack tip that initiates the crack growth in the glass material due to the presence of humidity, the rapid loading will shorten the time for the reaction in the crack tip and thus delay the occurrence of crack growth, resulting in a strength increase. Based on this hypothesis, the observed increase in strength was compared to Brown's integral (Brown 1972) to asses whether the static fatigue constant equal to 16 provides a good fit or not. The comparison indicated an increase of the constant for the high loading rates, however, a conclusion cannot be drawn as more tests would be needed.

\section{Conclusion}

A successful ring-on-ring test setup was developed to investigate the dynamic flexural strength of small circular sodalime-silica glass specimens. The testing fixture was designed for a custom-made servo-hydraulic high-speed test rig that was capable of producing and reproducing loading rates for the investigated specimens, comparable with SHPB tests. All specimens tested were subjected to a constant loading rate 
Table 1 Biaxial flexural strength of soda-lime-silica glass tested under different loading rates with the as-received and pre-damaged surface condition. ( $v_{p}=$ target piston velocity; $N=$ number of tests)

\begin{tabular}{|c|c|c|c|c|c|c|c|c|}
\hline \multirow[b]{2}{*}{$\begin{array}{c}v_{p} \\
{[\mathrm{~mm} / \mathrm{s}]}\end{array}$} & \multicolumn{4}{|c|}{ As-received } & \multicolumn{4}{|c|}{ Pre-damaged } \\
\hline & $\begin{array}{c}\dot{\sigma} \\
{[\mathrm{MPa} / \mathrm{s}]}\end{array}$ & $\begin{array}{c}\sigma_{f} \\
{[\mathrm{MPa}]}\end{array}$ & $\begin{array}{c}\dot{\varepsilon} \\
{\left[\mathrm{s}^{-1}\right]}\end{array}$ & $\begin{array}{l}N \\
{[-]}\end{array}$ & $\begin{array}{c}\dot{\sigma} \\
{[\mathrm{MPa} / \mathrm{s}]}\end{array}$ & $\begin{array}{c}\sigma_{f} \\
{[\mathrm{MPa}]}\end{array}$ & $\begin{array}{c}\dot{\varepsilon} \\
{\left[\mathrm{s}^{-1}\right]}\end{array}$ & $\begin{array}{l}N \\
{[-]}\end{array}$ \\
\hline $1.7 \cdot 10^{-3}$ & $2 \pm 0.2$ & $169 \pm 40$ & $2.2 \cdot 10^{-5}$ & 30 & $1 \pm 0.3$ & $56 \pm 6$ & $1.1 \cdot 10^{-5}$ & 5 \\
\hline 0.05 & $78 \pm 7$ & $211 \pm 50$ & $8.6 \cdot 10^{-4}$ & 10 & $62 \pm 6$ & $72 \pm 1$ & $6.8 \cdot 10^{-4}$ & 3 \\
\hline 1 & $1311 \pm 146$ & $263 \pm 86$ & $1.4 \cdot 10^{-2}$ & 15 & $1356 \pm 213$ & $82 \pm 3$ & $1.5 \cdot 10^{-2}$ & 3 \\
\hline 10 & $7646 \pm 504$ & $229 \pm 63$ & $8.4 \cdot 10^{-2}$ & 28 & $8269 \pm 272$ & $71 \pm 6$ & $9.1 \cdot 10^{-2}$ & 4 \\
\hline 100 & $1.2 \cdot 10^{5} \pm 2.6 \cdot 10^{4}$ & $248 \pm 92$ & $1.3 \cdot 10^{0}$ & 15 & $1.4 \cdot 10^{5} \pm 1.6 \cdot 10^{4}$ & $88 \pm 19$ & $1.5 \cdot 10^{0}$ & 4 \\
\hline 1000 * & $1.9 \cdot 10^{6} \pm 4.8 \cdot 10^{4}$ & $297 \pm 73$ & $2.1 \cdot 10^{1}$ & 16 & $1.5 \cdot 10^{6} \pm 1.4 \cdot 10^{5}$ & $85 \pm 13$ & $1.7 \cdot 10^{1}$ & 3 \\
\hline $3000^{\star}$ & $5.6 \cdot 10^{6} \pm 6.5 \cdot 10^{5}$ & $313 \pm 73$ & $6.2 \cdot 10^{1}$ & 15 & & & & \\
\hline
\end{tabular}

* Piston velocity where force equilibrium was not verified.

Table 2 Results of a one-way ANOVA conducted for the as-received and pre-damaged specimens. The degree of freedom $\left(d f=d f_{\text {between }}\right.$, $d f_{\text {within }}$ ) is given along with the value of $F$ and the significance (Sig.).

\begin{tabular}{lccc}
\hline & $d f$ & $F$ & Sig. \\
\hline As-received & 6,122 & 11.17 & $6.51 \cdot 10^{-10}$ \\
Pre-damaged & 5,16 & 6.06 & $2.48 \cdot 10^{-3}$ \\
\hline
\end{tabular}

until failure. This was ensured through load signals measured at the load ring and support ring. Furthermore, these signals were compared to verify force equilibrium. High-speed camera recordings along with FEM analysis, clearly indicated that the specimens failed in bending. The investigations have revealed that the flexural strength increases significantly with loading rate for both surface conditions tested. An increase in flexural strength of $85 \%$ was found for the specimens with an untreated surface. Applying a well-defined pre-damage to the surface has led to remarkable lower scattering of the test results, still showing the same behaviour as the untreated ones. A comparison between the test results and Brown's integral indicated that an increase of the static fatigue constant might have been present at the high loading rates. Despite the fact that the investigations showed promising results, the number of specimens needs to be increased due to the large scattering to get a more profound understanding of the dynamic flexural strength of soda-lime-silica glass.

Acknowledgements The authors acknowledge the research team of Prof. Dr.-Ing. J. Schneider from the Institute of Structural Mechanics and Design at TU Darmstadt, who has helped to pre-damage a number of the investigated glass specimens. Also, the authors are truly grateful to Z. I. Balogh from DTU CEN (Center for Electron Nanoscopy) for performing the SEM/EDS analysis.

\section{Appendix A: Full Experimental Results}

The experimental results of this study are listed in Table A1 for the as-received specimens and Table A2 for the pre-damaged ones, where the thickness of each specimen is given along with the target piston velocity, $v_{p}$, the recorded peak load, $F$, and the applied loading rate, $\dot{F}$.

Table A1 Experimental results for the as-received specimens.

\begin{tabular}{|c|c|c|c|c|}
\hline Test Nr. & $\begin{array}{l}\text { Thickness } \\
\text { [mm] }\end{array}$ & $\begin{array}{c}v_{p} \\
{[\mathrm{~mm} / \mathrm{s}]}\end{array}$ & $\begin{array}{c}F \\
{[\mathrm{kN}]}\end{array}$ & $\begin{array}{c}\dot{F} \\
{[\mathrm{kN} / \mathrm{s}]}\end{array}$ \\
\hline 1 & 2.90 & $1.7 \cdot 10^{-3}$ & 1.651 & 0.020 \\
\hline 2 & 2.88 & $1.7 \cdot 10^{-3}$ & 1.543 & 0.022 \\
\hline 3 & 2.85 & $1.7 \cdot 10^{-3}$ & 2.309 & 0.022 \\
\hline 4 & 2.83 & $1.7 \cdot 10^{-3}$ & 2.147 & 0.023 \\
\hline 5 & 2.86 & $1.7 \cdot 10^{-3}$ & 2.019 & 0.020 \\
\hline 6 & 2.84 & $1.7 \cdot 10^{-3}$ & 2.436 & 0.021 \\
\hline 7 & 2.86 & $1.7 \cdot 10^{-3}$ & 1.890 & 0.018 \\
\hline 8 & 2.87 & $1.7 \cdot 10^{-3}$ & 1.870 & 0.018 \\
\hline 9 & 2.89 & $1.7 \cdot 10^{-3}$ & 1.319 & 0.018 \\
\hline 10 & 2.83 & $1.7 \cdot 10^{-3}$ & 2.088 & 0.016 \\
\hline 11 & 2.86 & $1.7 \cdot 10^{-3}$ & 2.696 & 0.018 \\
\hline 12 & 2.85 & $1.7 \cdot 10^{-3}$ & 1.101 & 0.017 \\
\hline 13 & 2.83 & $1.7 \cdot 10^{-3}$ & 1.965 & 0.017 \\
\hline 14 & 2.86 & $1.7 \cdot 10^{-3}$ & 1.508 & 0.015 \\
\hline 15 & 2.89 & $1.7 \cdot 10^{-3}$ & 1.525 & 0.017 \\
\hline 16 & 2.84 & $1.7 \cdot 10^{-3}$ & 2.254 & 0.017 \\
\hline 17 & 2.84 & $1.7 \cdot 10^{-3}$ & 2.010 & 0.017 \\
\hline 18 & 2.85 & $1.7 \cdot 10^{-3}$ & 2.349 & 0.018 \\
\hline 19 & 2.86 & $1.7 \cdot 10^{-3}$ & 1.157 & 0.015 \\
\hline 20 & 2.89 & $1.7 \cdot 10^{-3}$ & 1.981 & 0.016 \\
\hline 21 & 2.84 & $1.7 \cdot 10^{-3}$ & 1.931 & 0.022 \\
\hline 22 & 2.84 & $1.7 \cdot 10^{-3}$ & 1.767 & 0.016 \\
\hline 23 & 2.84 & $1.7 \cdot 10^{-3}$ & 2.245 & 0.018 \\
\hline 24 & 2.84 & $1.7 \cdot 10^{-3}$ & 1.664 & 0.021 \\
\hline 25 & 2.87 & $1.7 \cdot 10^{-3}$ & 1.320 & 0.019 \\
\hline 26 & 2.83 & $1.7 \cdot 10^{-3}$ & 1.795 & 0.016 \\
\hline 27 & 2.83 & $1.7 \cdot 10^{-3}$ & 1.408 & 0.017 \\
\hline 28 & 2.89 & $1.7 \cdot 10^{-3}$ & 0.922 & 0.015 \\
\hline 29 & 2.84 & $1.7 \cdot 10^{-3}$ & 1.908 & 0.017 \\
\hline
\end{tabular}


Table A1-continued:

\begin{tabular}{|c|c|c|c|c|}
\hline Test Nr. & $\begin{array}{c}\text { Thickness } \\
\text { [mm] }\end{array}$ & $\begin{array}{c}v_{p} \\
{[\mathrm{~mm} / \mathrm{s}]}\end{array}$ & $\begin{array}{c}F \\
{[\mathrm{kN}]}\end{array}$ & $\begin{array}{c}\dot{F} \\
{[\mathrm{kN} / \mathrm{s}]}\end{array}$ \\
\hline 30 & 2.88 & $1.7 \cdot 10^{-3}$ & 1.498 & 0.016 \\
\hline 31 & 2.83 & 0.05 & $1.929^{-}$ & 0.828 \\
\hline 32 & 2.85 & 0.05 & 1.787 & 0.893 \\
\hline 33 & 2.88 & 0.05 & 1.392 & 0.922 \\
\hline 34 & 2.88 & 0.05 & 2.098 & 0.814 \\
\hline 35 & 2.84 & 0.05 & 2.443 & 0.901 \\
\hline 36 & 2.83 & 0.05 & 2.972 & 0.855 \\
\hline 37 & 2.82 & 0.05 & 1.960 & 0.843 \\
\hline 38 & 2.84 & 0.05 & 2.531 & 0.825 \\
\hline 39 & 2.86 & 0.05 & 3.154 & 0.820 \\
\hline 40 & 2.82 & 0.05 & 2.285 & 0.636 \\
\hline 41 & 2.84 & 1 & 2.238 & 16.86 \\
\hline 42 & 2.88 & 1 & 2.592 & 13.92 \\
\hline 43 & 2.87 & 1 & 3.715 & 13.63 \\
\hline 44 & 2.88 & 1 & 1.590 & 14.46 \\
\hline 45 & 2.85 & 1 & 3.829 & 13.04 \\
\hline 46 & 2.83 & 1 & 2.258 & 14.42 \\
\hline 47 & 2.85 & 1 & 3.640 & 12.99 \\
\hline 48 & 2.86 & 1 & 3.479 & 13.53 \\
\hline 49 & 2.85 & 1 & 1.515 & 12.30 \\
\hline 50 & 2.84 & 1 & 1.972 & 16.84 \\
\hline 51 & 2.85 & 1 & 3.844 & 14.79 \\
\hline 52 & 2.86 & 1 & 3.694 & 14.91 \\
\hline 53 & 2.85 & 1 & 2.423 & 13.03 \\
\hline 54 & 2.85 & 1 & 3.862 & 14.87 \\
\hline 55 & 2.85 & 1 & 1.650 & 10.99 \\
\hline 56 & 2.84 & 10 & 2.700 & 85.20 \\
\hline 57 & 2.90 & 10 & 2.466 & 84.75 \\
\hline 58 & 2.88 & 10 & 2.766 & 84.69 \\
\hline 59 & 2.88 & 10 & 2.412 & 85.45 \\
\hline 60 & 2.89 & 10 & 1.930 & 89.65 \\
\hline 61 & 2.83 & 10 & 1.254 & 76.22 \\
\hline 62 & 2.87 & 10 & 1.397 & 81.47 \\
\hline 63 & 2.84 & 10 & 2.388 & 82.15 \\
\hline 64 & 2.85 & 10 & 1.549 & 84.65 \\
\hline 65 & 2.84 & 10 & 2.734 & 80.50 \\
\hline 66 & 2.85 & 10 & 1.728 & 86.06 \\
\hline 67 & 2.86 & 10 & 2.232 & 83.79 \\
\hline 68 & 2.84 & 10 & 2.065 & 86.31 \\
\hline 69 & 2.87 & 10 & 3.203 & 81.52 \\
\hline 70 & 2.88 & 10 & 3.232 & 82.40 \\
\hline 71 & 2.87 & 10 & 2.170 & 84.42 \\
\hline 72 & 2.82 & 10 & 1.744 & 76.86 \\
\hline 73 & 2.82 & 10 & 2.807 & 75.25 \\
\hline 74 & 2.84 & 10 & 3.210 & 70.64 \\
\hline 75 & 2.87 & 10 & 2.554 & 77.40 \\
\hline 76 & 2.87 & 10 & 2.924 & 75.21 \\
\hline 77 & 2.85 & 10 & 4.503 & 80.28 \\
\hline 78 & 2.86 & 10 & 2.867 & 75.09 \\
\hline 79 & 2.86 & 10 & 2.270 & 83.24 \\
\hline 80 & 2.83 & 10 & 2.966 & 72.95 \\
\hline 81 & 2.84 & 10 & 2.097 & 81.91 \\
\hline 82 & 2.87 & 10 & 2.068 & 93.73 \\
\hline 83 & 2.87 & 10 & 2.521 & 90.03 \\
\hline 84 & 2.88 & 100 & $1.97 \overline{4}^{-}$ & 1208.9 \\
\hline 85 & 2.86 & 100 & 3.324 & 974.8 \\
\hline 86 & 2.83 & 100 & 3.021 & 1196.0 \\
\hline 87 & 2.89 & 100 & 1.367 & 1569.6 \\
\hline 88 & 2.89 & 100 & 3.432 & 943.2 \\
\hline
\end{tabular}

Table A1 - continued:

\begin{tabular}{|c|c|c|c|c|}
\hline Test Nr. & $\begin{array}{c}\text { Thickness } \\
{[\mathrm{mm}]}\end{array}$ & $\begin{array}{c}v_{p} \\
{[\mathrm{~mm} / \mathrm{s}]}\end{array}$ & $\begin{array}{c}F \\
{[\mathrm{kN}]}\end{array}$ & $\begin{array}{c}\dot{F} \\
{[\mathrm{kN} / \mathrm{s}]}\end{array}$ \\
\hline 89 & 2.84 & 100 & 1.422 & 1635.4 \\
\hline 90 & 2.84 & 100 & 2.918 & 1362.0 \\
\hline 91 & 2.85 & 100 & 1.231 & 1517.4 \\
\hline 92 & 2.85 & 100 & 3.509 & 955.7 \\
\hline 93 & 2.84 & 100 & 3.578 & 919.0 \\
\hline 94 & 2.85 & 100 & 1.992 & 1556.7 \\
\hline 95 & 2.88 & 100 & 2.743 & 1326.1 \\
\hline 96 & 2.86 & 100 & 4.514 & 907.3 \\
\hline 97 & 2.86 & 100 & 3.070 & 1136.3 \\
\hline 98 & 2.87 & 100 & 1.732 & 1602.9 \\
\hline 99 & 2.88 & 1000 & $3.712^{-}$ & $20000 . \overline{8}$ \\
\hline 100 & 2.84 & 1000 & 2.965 & 19793.7 \\
\hline 101 & 2.82 & 1000 & 2.385 & 20167.5 \\
\hline 102 & 2.83 & 1000 & 3.725 & 19277.5 \\
\hline 103 & 2.82 & 1000 & 2.926 & 19804.4 \\
\hline 104 & 2.83 & 1000 & 2.191 & 19345.5 \\
\hline 105 & 2.87 & 1000 & 2.235 & 19850.8 \\
\hline 106 & 2.84 & 1000 & 3.290 & 20232.3 \\
\hline 107 & 2.82 & 1000 & 2.512 & 19787.0 \\
\hline 108 & 2.82 & 1000 & 3.438 & 19354.4 \\
\hline 109 & 2.85 & 1000 & 3.184 & 19739.3 \\
\hline 110 & 2.85 & 1000 & 5.128 & 20043.2 \\
\hline 111 & 2.85 & 1000 & 2.895 & 21135.0 \\
\hline 112 & 2.85 & 1000 & 4.259 & 20600.9 \\
\hline 113 & 2.85 & 1000 & 3.518 & 19163.5 \\
\hline 114 & 2.86 & 1000 & 2.566 & 19432.0 \\
\hline $115^{-}$ & 2.87 & 3000 & $3.0 \overline{7} \overline{8}^{-}$ & 61364.1 \\
\hline 116 & 2.82 & 3000 & 3.001 & 56450.1 \\
\hline 117 & 2.83 & 3000 & 2.850 & 60570.4 \\
\hline 118 & 2.83 & 3000 & 2.789 & 67101.8 \\
\hline 119 & 2.83 & 3000 & 5.325 & 52780.3 \\
\hline 120 & 2.84 & 3000 & 3.045 & 57295.2 \\
\hline 121 & 2.86 & 3000 & 2.850 & 67464.9 \\
\hline 122 & 2.82 & 3000 & 2.845 & 70278.0 \\
\hline 123 & 2.83 & 3000 & 2.787 & 64705.5 \\
\hline 124 & 2.84 & 3000 & 3.376 & 47051.0 \\
\hline 125 & 2.85 & 3000 & 2.721 & 70446.1 \\
\hline 126 & 2.87 & 3000 & 2.998 & 65229.4 \\
\hline 127 & 2.89 & 3000 & 4.125 & 55789.0 \\
\hline 128 & 2.85 & 3000 & 3.773 & 54517.8 \\
\hline 129 & 2.86 & 3000 & 4.634 & 56162.8 \\
\hline
\end{tabular}

Table A2 Experimental results for the pre-damaged specimens.

\begin{tabular}{ccccc}
\hline Test Nr. & $\begin{array}{c}\text { Thickness } \\
{[\mathrm{mm}]}\end{array}$ & $\begin{array}{c}v_{p} \\
{[\mathrm{~mm} / \mathrm{s}]}\end{array}$ & $\begin{array}{c}F \\
{[\mathrm{kN}]}\end{array}$ & $\begin{array}{c}\dot{F} \\
{[\mathrm{kN} / \mathrm{s}]}\end{array}$ \\
\hline 1 & 2.86 & $1.7 \cdot 10^{-3}$ & 0.648 & 0.009 \\
2 & 2.86 & $1.7 \cdot 10^{-3}$ & 0.550 & 0.009 \\
3 & 2.82 & $1.7 \cdot 10^{-3}$ & 0.641 & 0.016 \\
4 & 2.87 & $1.7 \cdot 10^{-3}$ & 0.627 & 0.008 \\
5 & 2.84 & $1.7 \cdot 10^{-3}$ & 0.505 & 0.008 \\
\hline 6 & 2.84 & 0.05 & 0.775 & 0.593 \\
7 & 2.86 & 0.05 & 0.777 & 0.661 \\
8 & 2.84 & 0.05 & 0.753 & 0.725 \\
-9 & 2.85 & 1 & 0.913 & 17.05 \\
10 & 2.84 & 1 & 0.882 & 12.66 \\
\hline
\end{tabular}


Table A2 - continued:

\begin{tabular}{|c|c|c|c|c|}
\hline Test Nr. & $\begin{array}{c}\text { Thickness } \\
\text { [mm] }\end{array}$ & $\begin{array}{c}v_{p} \\
{[\mathrm{~mm} / \mathrm{s}]}\end{array}$ & $\begin{array}{c}F \\
{[\mathrm{kN}]}\end{array}$ & $\begin{array}{c}\dot{F} \\
{[\mathrm{kN} / \mathrm{s}]}\end{array}$ \\
\hline 11 & 2.84 & 1 & 0.851 & 13.82 \\
\hline 12 & 2.85 & 10 & $0 . \overline{8} \overline{8}$ & $\overline{9} \overline{8} \overline{3}$ \\
\hline 13 & 2.83 & 10 & 0.764 & 87.36 \\
\hline 14 & 2.84 & 10 & 0.712 & 87.53 \\
\hline 15 & 2.86 & 10 & 0.705 & 86.39 \\
\hline 16 & 2.85 & 100 & $1.203^{-}$ & 1648.0 \\
\hline 17 & 2.84 & 100 & 0.957 & 1609.0 \\
\hline 18 & 2.84 & 100 & 0.866 & 1582.9 \\
\hline 19 & 2.88 & 100 & 0.733 & 1277.4 \\
\hline 20 & 2.85 & $1000^{-}$ & $1.07 \overline{2}^{-}$ & 179588.4 \\
\hline 21 & 2.85 & 1000 & 0.821 & 15944.9 \\
\hline 22 & 2.85 & 1000 & 0.833 & 14999.8 \\
\hline
\end{tabular}

\section{References}

ASTM C1499 (2015). Test Method for Monotonic Equibiaxial Flexural Strength of Advanced Ceramics at Ambient Temperature. Annual Book of ASTM Standards C1499 - 15. ASTM International, West Conshohocken, PA.

Brown, W. G. (1972). A load duration theory for glass design. Publication NRCC 12354, pages 75-78, doi:http://doi.org/10.4224/20374822.

Datsiou, K. C. and Overend, M. (2017a). Artificial ageing of glass with sand abrasion. Construction and Building Materials, 142:536-551, doi:10.1016/j.conbuildmat.2017.03.094.

Datsiou, K. C. and Overend, M. (2017b). The strength of aged glass. Glass Structures \& Engineering, 2(2):105-120, doi:10.1007/s40940-017-0045-6.

Del Linz, P., Hooper, P. A., Arora, H., Wang, Y., Smith, D., Blackman, B. R., and Dear, J. P. (2017). Delamination properties of laminated glass windows subject to blast loading. International Journal of Impact Engineering, 105:39-53, doi:10.1016/j.ijimpeng.2016.05.015.

EN 572-1:2012 (2012). Glass in building - Basic soda lime silicate glass products - Part 1: Definitions and general physical and mechanical properties. European Committee for Standardization (CEN), Avenue Marnix 17, B-1000 Brussels.

Evans, A. G. and Wiederhorn, S. M. (1974). Proof testing of ceramic materials-an analytical basis for failure prediction. International Journal of Fracture, 26(4):355-368, doi:10.1007/BF00962969.

Hilcken, J. (2015). Zyklische Ermüdung von thermisch entspanntem und thermisch vorgespanntem Kalk-Natron-Silikatglas. PhD thesis, Technische Universität Darmstadt.

Hooper, P., Sukhram, R., Blackman, B., and Dear, J. (2012). On the blast resistance of laminated glass. International Journal of Solids and Structures, 49(6):899-918, doi:10.1016/j.ijsolstr.2011.12.008.

Kuntsche, J. (2015). Mechanisches Verhalten von Verbundglas unter zeitabhängiger Belastung und Explosionsbeanspruchung. $\mathrm{PhD}$ thesis, Technische Universität Darmstadt.

Larcher, M., Solomos, G., Casadei, F., and Gebbeken, N. (2012). Experimental and numerical investigations of laminated glass subjected to blast loading. International Journal of Impact Engineering, 39(1):42-50, doi:10.1016/j.ijimpeng.2011.09.006.

Michalske, T. A. and Freiman, S. W. (1983). A Molecular Mechanism for Stress Corrosion in Vitreous Silica. Journal of the American Ceramic Society, 66(4):284-288, doi:10.1111/j.11512916.1983.tb15715.x.

Nie, X., Chen, W. W., and Templeton, D. W. (2010). Dynamic Ringon-Ring Equibiaxial Flexural Strength of Borosilicate Glass. International Journal of Applied Ceramic Technology, 7(5):616-624, doi:10.1111/j.1744-7402.2010.02508.x.
Nie, X., Chen, W. W., Wereszczak, A. A., and Templeton, D. W. (2009). Effect of loading rate and surface conditions on the flexural strength of borosilicate glass. Journal of the American Ceramic Society, 92(6):1287-1295, doi:10.1111/j.1551-2916.2009.03019.x.

Norville, H. S. (2000). Closure to "Glass-Related Injuries in Oklahoma City Bombing". Journal of Performance of Constructed Facilities, 14(4): 167.

Norville, H. S., Harvill, N., Conrath, E. J., Shariat, S., and Mallonee, S. (1999). Glass-Related Injuries in Oklahoma City Bombing. Journal of Performance of Constructed Facilities, 13(2):50-56.

Pelfrene, J. (2016). Numerical analysis of the post-fracture response of laminated glass under impact and blast loading. $\mathrm{PhD}$ thesis, Ghent University.

Peroni, M., Solomos, G., Pizzinato, V., and Larcher, M. (2011). Experimental Investigation of High Strain-Rate Behaviour of Glass. Applied Mechanics and Materials, 82:63-68, doi:10.4028/www.scientific.net/AMM.82.63.

Schula, S. (2015). Charakterisierung der Kratzanfälligkeit von Gläsern im Bauwesen. $\mathrm{PhD}$ thesis, Technische Universität Darmstadt.

Swab, J. J., Patel, P. J., Tran, X., Gilde, L., Luoto, E., Gaviola, M. H., Gott, A., Paulson, B., and Kilczewski, S. (2014). Equibiaxial Flexure Strength of Glass: Influence of Glass Plate Size and Equibiaxial Ring Ratio. International Journal of Applied Glass Science, 5(4):384-392, doi:10.1111/ijag.12094.

Timoshenko, S. and Woinowsky-Krieger, S. (1976). Theory of plates and shells. McGraw-Hill.

Wiederhorn, S. and Bolz, L. (1970). Stress corrosion and static failure of glass. Journal American Society of Ceramics, 53(474):543-548, doi:10.1111/j.1151-2916.1970.tb15962.x.

Wiederhorn, S. M. (1967). Influence of Water Vapor on Crack Propagation in Soda-Lime Glass. Journal of the American Ceramic Society, 50(8):407-414, doi:10.1111/j.1151-2916.1967.tb15145.x.

Zhang, X., Hao, H., and Ma, G. (2013). Parametric study of laminated glass window response to blast loads. Engineering Structures, 56:1707-1717, doi:10.1016/j.engstruct.2013.08.007.

Zhang, X., Zou, Y., Hao, H., Li, X., Ma, G., and Liu, K. (2012). Laboratory Test on Dynamic Material Properties of Annealed Float Glass. International Journal of Protective Structures, 3(4):407-430, doi:10.1260/2041-4196.3.4.407. 